\title{
THE ANALYSIS OF SERBIAN CUSTOMERS SATISFACTION WITH E-SERVICES QUALITY DIMENSIONS OF LODGING E-INTERMEDIARIES
}

\author{
Nikola Mihajlović ${ }^{1 *}$ \\ ${ }^{1}$ Singidunum University, \\ 32 Danijelova Street, Belgrade, Serbia
}

\begin{abstract}
:
With the constantly rising share of online accommodation bookings, finding out how customers perceive the website e-service quality is becoming increasingly important in order to build strong satisfaction and create loyal customers. The main goal of the study was to analyze how Serbian customers perceive the quality of service provided by lodging e-intermediaries. Correlation matrix and multiple regression analysis were used to determine the impact of each of 6 e-service quality dimensions on satisfaction of e-intermediary customers. The questionnaires were distributed during the research period of 3 months (July-September, 2015). The study has shown that only three out of six dimensions have impact on customer satisfaction, comprising $63.9 \%$ of total customer satisfaction: reliability, information quality, and personalization.
\end{abstract}

\section{Key words:}

service quality, online shopping,

Serbia,

customer satisfaction, e-intermediaries.

\section{INTRODUCTION}

Information technologies have a significant influence on the tourism as a whole, especially the rise of the Internet which accelerated innovation in the tourism sector. Predictions are that this trend will continue (Avdimiotis et al., 2009).

The worldwide number of Internet users is constantly growing, followed by the growing number of Internet users purchasing online. This trend affected the hotel industry too, with online sales today being an indispensable distribution channel for hotels, regardless of their size, category or location. The overall number of accommodation bookings over the Internet is constantly growing, which is confirmed each year by numerous researchers. According to Phocuswrite, in some developed countries and regions of the 
world, booking accommodation over the Internet makes up more than $40 \%$ of the total number of bookings (Europe - 45\%, USA - 43\%). In developing countries, this percentage is significantly lower (Eastern Europe - 27\%), but it records constant and higher growth. The average growth in the period 2011-2015 for Eastern Europe accounted for $25 \%$, which is several times more than in Europe $(8 \%)$ or the US (7\%) (World Travel Market, 2015). Tourism is an information-intensive industry with information exchange between the seller and the buyer carrying a high risk of losing quality of information or misunderstanding. The value of information is derived from its systematicity, comprehensiveness, completeness, objectivity and specificity (Popesku, 2011). Internet and e-commerce are enabling greater interactivity and flexibility of operations, faster and cheaper operations compared to traditional, higher level of integration of business segments, etc (Vitić-Ćetković, 2009). Following this trend, there is the need to understand how customers perceive the e-service quality (e-SQ) when purchasing accommodation. Having a high service quality and satisfied customers is an important goal in the strategy of any successful organization. Thus, a large number of research studies have been done in this field.

According to data of the Serbian Statistical Office in 2015 (Kovačević et al., 2015), 65.3\% of people used the Internet in the last three months, following the continuous growth of the Internet users in Serbia over the past years. Although the number of internet users in Serbia, who bought or ordered goods or services online over the past 12 months, increased in the last three years by $11 \%$ (33.3\% in 2015 compared to $22 \%$ in 2012), the number of those users who have purchased accommodation online grew in the same period by only $2.8 \%$, which is significantly smaller percentage of growth in relation to the total increase of users who purchase goods and services online (Vukmirović et al. 2012).
The questions are what causes this situation, what Internet users in Serbia expect while purchasing accommodation online and whether the customers perceive website service as satisfactory. The particular research focus of this study was the use of lodging e-intermediaries, namely Online Travel Agencies (OTA), companies operating online which mediate between companies that provide tourist services and its customers (Davidson \& Burgess, 2006).

Therefore, the research problem was exploring the e-SQ dimensions of lodging e-intermediaries when purchasing accommodation and their impact on the satisfaction of Serbian customers. The goal was to answer what e-SQ dimensions affect Serbian user satisfaction the most, from the aspect of quality of e-service provided by lodging e-intermediaries.

\section{LITERATURE REVIEW}

\section{Service quality}

Most studies on customer perceived satisfaction of provided service are based on traditional models. One of the most widely used and most well-known models for customer satisfaction research is certainly the SERVQUAL model. Parasuraman et al. (2005) note that the literature on the subject of service quality is dominated by the research of the services provided by the people - the traditional concept of quality of service. However, purchasing online (e-commerce) means that the customers are primarily interacting with the website instead of the person as the service provider. Therefore, the question remains as to whether the conclusions of the traditional service quality research are valid in the context of services provided online, where the interaction takes place between customers and technology, as well as determining how similar the process of evaluation of the traditional quality of service is compared to quality of electronic services. 
The quality of e-services can be defined as the customers' overall evaluation and judgment of the excellence and quality of e-services offerings in the electronic environments (Santos, 2003, quoted in Bauernfeind et al., 2006).

Zeithaml et al. (2002) defined the concept of e-services quality as "extent to which a website facilitates efficient and effective shopping, purchasing, and delivery of products and services" (Zeithaml et al., 2002). Furthermore, Zeithaml et al. (2009) identified neither low price nor quality of the website as the key success factors for the company that uses the latest technology, but the e-SQ.

According to Bogdanovych et al. (2007), there is a shift in user preferences from products and services to experiences. For many travelers, the service has become secondary, and service providers must provide the user experience above the basics. Only good service is not enough. Travelers nowadays decide on the purchase based on the quality of experience they receive in the course of travel choices. It is unlikely that customers will thoroughly evaluate each sub-process during online purchase, but will rather perceive the service as an overall process and outcome (van Riel et al., 2001, cited in Lee \& Lin, 2005). Also, the customer-specific attributes can influence the attributes that customers desire in an ideal website and the performance levels that would signal the superior e-service quality (e-SQ) (Parasuraman et al., 2005).

Udo et al. (2010) have shown that the benefits offered by the provider and the content of the website have a significant positive effect on the customers' e-SQ perception. Although, unlike the traditional service quality research, e-SQ research is at the initial stage (Serkan et al., 2010), a number of previous studies suggest that the e-service satisfaction, and consequently the behavioral intentions of consumer or e-loyalty, are largely influenced by the quality of e-services provided (Lee \& Lin, 2005; Cristobal et al., 2007; Cyr, 2008; Marimon et al., 2010; Bernardo et al., 2012 ; Alonso-Almeida et al., 2014).

\section{E-service quality research models}

Yoo \& Donthu (2001) developed the nineitem scale of SITE-QUAL with the following four dimensions of quality: ease of use, aesthetic design, processing speed, and security quality dimensions ( $\mathrm{Su}, 2014)$.

Loiacono et al. (2002) developed WebQual, a scale with 12 dimensions which is developed at several stages, in different domains, providing information mainly regarding the web site design while having limited results when it comes to service quality as experienced by customers. According to Barnes \& Vidgen (2002), despite the provision of a valid profile of e-SQ, WebQual does not give descriptive advice on how an organization can improve its online sales and services.

Wolfinbarger \& Gilly (2003) developed a four-dimensional eTailQ scale: website design, reliability/fulfillment, privacy/security and customer service.

Zeithaml et al. (2000, 2002) and Parasuraman et al. (2005) conducted a study related to the quality of internet services having their previous research of the quality of services provided through the traditional distribution channels as starting point, which resulted in development of ES-QUAL scale with four dimensions (out of the original 11 dimensions) and E-RecSQAUL three-dimensional e-recovery service quality scale.

In addition to these models, a number of researchers offered additional models which were modified in order to be more adjusted to specific questions and research problems. As most of the research was concentrated on the online retailing services or the quality of the website design, Cristobal et al. (2007) have proposed a four-dimensional model indicating other aspects of eservices, in addition to the design and usability, which affect the consumer's perception of eSQ, called PESQ, and include web design, customer service, assurance and order management. This model was modified with the aim to provide 
the analysis of profits generated by higher perceived quality in terms of user satisfaction and loyalty, which is also considered by Smith \& Synowka (2014) as not fully analyzed. Raman et al. (2008) were doing research on the Internet banking adoption and suggested a model with six dimensions of quality e-services: ease of use, appearance, reliability, customization, communication and incentive. Swaida \& Wigand (2009) also proposed a six-dimensional model: website usability, information quality, reliability, responsiveness, assurance and personalization. They identified that individual e-service quality dimensions are related to different types of customer loyalty (e.g. whether the loyalty is tied to the price or personal preferences). Santouridis \& Krikoni (2016) added two dimensions to E-S-QUAL model aiming to include e-SQ hedonic aspects. Among them is the modified model E-S-QUAL, developed by Bauernfeind et al. (2006) intended to study the online $\mathrm{B} 2 \mathrm{C}$ recommender systems quality of service, which was used as the basis for the herein conducted research (Figure 1).

\section{RESEARCH MODEL AND HYPOTHESES}

\section{Research Model}

Starting from initial areas of E-S-QUAL scale, an e-service quality instrument developed by Parasuraman et al. (2005), which has been identified by Zeithaml et al. (2000), Bauernfeind et al. (2006), conducted a study intended to research the e-SQ of 15 online $\mathrm{B} 2 \mathrm{C}$ recommender systems. The main goal of their research was to develop a research instrument which would be more suitable for recommender systems e-SQ research, having in mind the non-profit context of some recommender websites and lack of emphasis of personalization of the search and configuration process and the conversational character of this process within the existing instruments. As a result, they developed the scale with six dimensions of e-SQ (System Availability/Reliability, Structure/Usability, Information Quality, Efficiency, Safety/Privacy, and Personalization) with a total number of 22 items.

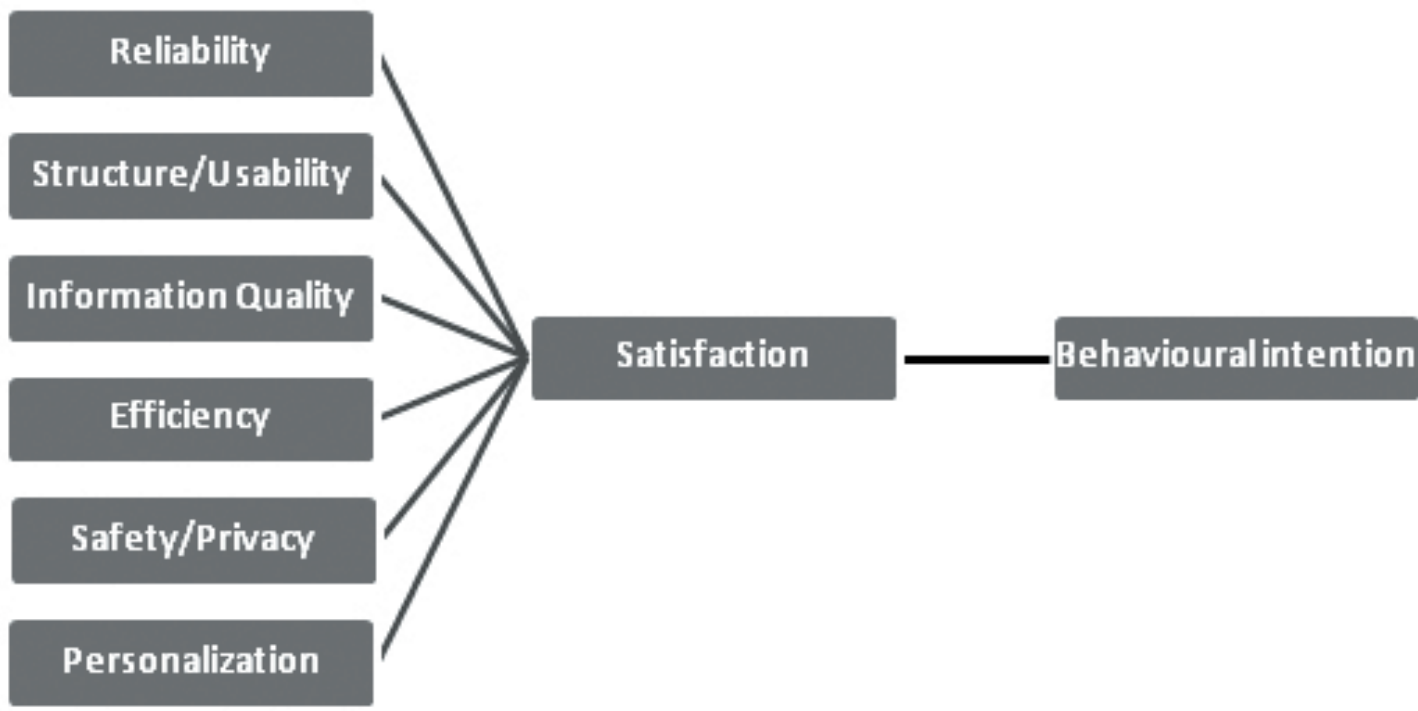

Figure 1. - Structural model developed by Bauernfeind et al. (2006). 


\section{E-service quality dimensions and development of hypotheses}

Research developed by Bauernfeind et al. (2006), which also included some of the lodging e-intermediaries, was considered the best suitable model for this research having in mind the similarities (almost half of the e-intermediaries used in the Bauernfeind et al. (2006) research were lodging e-intermediaries). As the analysis of Serbian customers perception of e-SQ provided by lodging e-intermediaries and their impact on satisfaction was the primary goal of the study, the question imposes as to which of the six dimensions defined by Bauernfeind et al. (2006) have an impact on satisfaction perceived by Serbian customers.

In accordance with the research problems, and the dimensions of the model used, six starting hypothesis were defined:

- Hypothesis 1: "System Availability/ Reliability has positive influence on e-SQ satisfaction".

- Hypothesis 2: "Structure/Usability has positive influence on e-SQ satisfaction".

- Hypothesis 3: “The Information Quality has positive influence on e-SQ satisfaction".

- Hypothesis 4: "Efficiency has positive influence on e-SQ satisfaction".

- Hypothesis 5: "Safety/Privacy has positive influence on e-SQ satisfaction".

- Hypothesis 6: "Personalization has positive influence on e-SQ satisfaction".

\section{RESEARCH METHODOLOGY}

\section{Measures}

As mentioned, the model developed by Bauernfeind et al. (2006) was used as a basis for the questionnaire used in the survey conducted herein. The collection of information about the user experience in the process of booking accommodation through lodging e-intermediaries, as well as showing the impact of individual e-SQ dimensions on the overall consumer satisfaction, were the main directions of the questionnaire design process.

A seven-point Likert scale was used for measuring e-service quality items, anchored at one (completely irrelevant / fully disagree) and seven(very important / fully agree), representing the extent to which respondents agree or disagree with the statements. The questionnaire consisted of two parts. The first part was designed to gather the basic information about customers, as well as information on habits and use of lodging e-intermediaries for booking accommodation. The second part of the questionnaire which refers to dimensions and aspects of the e-SQ provided by a websites, has a total of 25 items of which 22 are related to the e-SQ dimensions (6 dimensions) with the remaining three items related to customer satisfaction (Table 1). Given that this research relates to to a narrower field of research than Bauernfeind et al. study, focusing exclusively on lodging e-intermediaries, individual items of the questionnaire were adapted accordingly.

\section{Subjects and procedure}

Research questions and hypotheses were done on the basis of the existing models of e-SQ research and literature references. In order to further ensure the validity of the research, the authors have conducted a pilot test with ten $\mathrm{PhD}$ students from several universities in Serbia who reviewed the original questionnaire, after which the final version was developed. Given that this research was intended solely for citizens of Serbia, the questionnaire was made only in Serbian, and distributed over the Internet and in printed form. The online questionnaire was created as an online form for easier automated data collection.

The sample was formed by using the convenience sampling. A total of 384 question- 
Mihajlović N. $\diamond$ The analysis of Serbian customers satisfaction with e-services quality dimensions of lodging e-intermediaries

\section{e-SQ dimensions}

System Availability/Reliability

\section{Questionnaire items}

The website is immediately available and does not need long loading times.

The website operates without problems.

The website's structure is good.

Type face and size are appropriate.

A booking procedure is clearly structured and traceable.

The user finds easily what he/she is looking for.

The user gets sufficient additional information about the property.

The recommendations are clearly arranged.

The system gives sufficient information about the accommodation.

The recommendations are up-to-date.

Recommendations can be obtained with a minimum of effort (data input).

A comparison between properties, rates and offers is easily available.

The recommendations meet my expectations regarding usefulness and quality.

The system enables me to get results quickly.

Enough information about security issues is given at this web site.

The user is informed about the handling and utilization of personal data.

Security standards seem to be sufficient.

Information about the security system appears to be sufficient.

The use of a security certificate is announced explicitly.

Personalization
I had the impression that the recommendations and suggestions are targeted to my user profile. 


\begin{tabular}{ll}
\hline \multicolumn{1}{c}{ e-SQ dimensions } & \multicolumn{1}{c}{ Questionnaire items } \\
\hline Customer Satisfaction & $\begin{array}{l}\text { The impression was given that the system } \\
\text { considers my preferences and constraints. }\end{array}$ \\
\hline The bookings can be individually tailored. \\
\hline
\end{tabular}

Table 1. - E-SQ dimensions and questionnaire items of research model, Bauernfeind, 2016.

naires were collected in the period from July 2015 to September 2015. This period was chosen because of the holiday season with the assumption that larger number of customers would be more active in this period from the aspect of booking accommodation online. The research time-frame of three months was set to minimize the possibility of significant changes and differences in the perceptions in order to additionally insure the validity of the study.

All the data collected were from customers who had previously used the lodging e-intermediaries. Out of the total number of questionnaires, only 148 questionnaires or $38.54 \%$ were valid, and met the pre-requirements that the respondent was a citizen of Serbia and that the respondent booked accommodation through any lodging e-intermediary in the last twelve months. Only fully completed questionnaires were taken into consideration for further processing.

Out of the total number of respondents, $56.75 \%$ belong to the age group of $25-34$, and $12.16 \%$ are respondents who belong to the age group of 4554. The largest number of respondents (89.19\%) have college or higher university education, and $87.84 \%$ are employed or students. If compared with the total population of customers from Serbia who were purchasing accommodation online, it is obvious that this sample largely coincided with the total population of these users in Serbia. The relationship of individual dimensions of the e-SQ and their impact on total customer satisfaction was a potential reason for the relatively slow growth in the number of users from Serbia who purchase accommodation online.

\section{Statistical analysis}

SPSS 20 software was used for all data analyses. Research reliability was confirmed by using Crombach's Alpha, which was 0.942 for the whole research, while individual coefficients of all dimensions were greater than 0.800 , except for Usability that has an acceptable coefficient of 0.647, with cross-correlations higher than 0.3.

Pearson correlation matrix was used to indicate the relationship straight between the variables assumed in the hypotheses (Satapathy et al., 2013). The proposed hypotheses were tested by the use of multiple regression analysis to determine the impact level of e-SQ dimensions on the overall satisfaction. 


\section{RESULTS}

\section{Demographics, use of accommodation booking e-intermediaries and service quality satisfaction}

The first part of the research aimed to present the demographic data in this study and to indicate the way in which customers use lodging e-intermediaries to find and book accommodation. Most of the respondents were women (58.11\%), while most of the examined persons aged $25-44$ years $(81.08 \%)$. The majority of respondents are employed (82.43\%) and have college or university degree (89.19\%). Having used the convenience sampling method, a relatively large number of highly educated respondents is understandable and expected, given that the majority of respondents was obtained through university and business networks and groups on social networks.

Serbian customers book accommodation via e-intermediaries up to 10 times a year, mostly for stays of maximum six nights and with no preferences when it comes to the reason for traveling (business or pleasure). Most customers begin the process of booking accommodation by going directly to the homepage of the preferred e-intermediaries or use Google search. The most commonly used e-intermediary is Booking.com. During the selection process, the majority of Serbian customers will compare multiple properties, usually even 15 and more, and will mostly book double rooms in hotels, while other types of properties are about equally represented.

The following section of the questionnaire examines the six dimensions of e-SQ and the user perception of satisfaction with the lodging e-intermediaries service. The means for individual dimensions show that Serbian customers expressed the lowest satisfaction with Security (4.989) and Personalization (5.527). On the other hand, Reliability (6.318) and Usability (6.098) are the dimensions that customers were most satisfied with, though satisfaction with the Information quality (5.905) and Efficiency (5.804) show average values.
The item that customers are most satisfied with is "The web site is immediately available and does not need long loading times" indicating that the access speed is very important for customers from Serbia. Accordingly, another item that customers are most satisfied with is "The website operates without problems". Upon observing the first five aspects that customers are the most satisfied with, it is clear that the speed of website access and fast and easy booking process are very important for Serbian lodging e-intermediary customers.

On the other hand, items that customers are most dissatisfied with show that the greatest concern of lodging e-intermediary customers is safety and use of personal data. An overview of mentioned items shows that people are not completely confident that their data are well guarded and will not be abused, or that the possibility of their misuse is excluded.

\section{Pearson correlation matrix}

The following correlation matrix indicates that the e-SQ dimensions show a positive correlation with customer satisfaction. Dependent (customer satisfaction) and independent variables (e-SQ dimensions) both show the correlation coefficients smaller than 0.700 , indicating that there is no multicollinearity (Sekaran and Bougie, 2010).

A significant positive relationship can be seen between the e-SQ dimensions and satisfaction, with Information Quality having the strongest relationship of 0.695 , followed by Efficiency (0.642) and Personalization (0.630), while the weakest relationship is with safety (0.461). This research shows that the information quality is the most dominant of e-SQ dimension for Serbian customers.

\section{Regression analysis}

Regression analysis was used to test e-SQ dimensions against the customer satisfaction. Hypotheses were tested to determine e-SQ dimensions significance to customer service. 


\begin{tabular}{|c|c|c|c|c|c|c|c|c|}
\hline & & $\begin{array}{l}\text { Customer } \\
\text { Satisfaction }\end{array}$ & $\begin{array}{c}\text { System } \\
\text { Availability/ } \\
\text { Reliability }\end{array}$ & Usability & $\begin{array}{c}\text { Information } \\
\text { Quality }\end{array}$ & Efficiency & $\begin{array}{l}\text { Safety/ } \\
\text { Privacy }\end{array}$ & $\begin{array}{l}\text { Personali- } \\
\text { zation }\end{array}$ \\
\hline & $\begin{array}{l}\text { Customer } \\
\text { Satisfaction }\end{array}$ & 1.000 & 0.572 & 0.591 & 0.695 & 0.642 & 0.461 & 0.630 \\
\hline \multirow{5}{*}{ 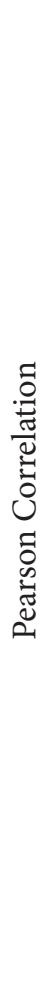 } & $\begin{array}{c}\text { System } \\
\text { Availability/ } \\
\text { Reliability }\end{array}$ & 0.572 & 1.000 & 0.668 & 0.442 & 0.490 & 0.290 & 0.424 \\
\hline & Usability & 0.591 & 0.668 & 1.000 & 0.618 & 0.671 & 0.440 & 0.447 \\
\hline & $\begin{array}{c}\text { Information } \\
\text { Quality }\end{array}$ & 0.695 & 0.442 & 0.618 & 1.000 & 0.659 & 0.531 & 0.478 \\
\hline & $\begin{array}{l}\text { Safety/ } \\
\text { Privacy }\end{array}$ & 0.461 & 0.290 & 0.440 & 0.531 & 0.511 & 1.000 & 0.598 \\
\hline & $\begin{array}{l}\text { Personali- } \\
\text { zation }\end{array}$ & 0.630 & 0.424 & 0.447 & 0.478 & 0.541 & 0.598 & 1.000 \\
\hline \multirow{5}{*}{ 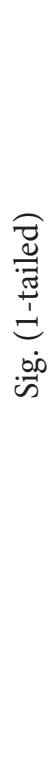 } & $\begin{array}{l}\text { Customer } \\
\text { Satisfaction }\end{array}$ & · & 0.000 & 0.000 & 0.000 & 0.000 & 0.000 & 0.000 \\
\hline & $\begin{array}{c}\text { System } \\
\text { Availability/ } \\
\text { Reliability }\end{array}$ & 0.000 & . & 0.000 & 0.000 & 0.000 & 0.000 & 0.000 \\
\hline & Usability & 0.000 & 0.000 & . & 0.000 & 0.000 & 0.000 & 0.000 \\
\hline & $\begin{array}{c}\text { Information } \\
\text { Quality }\end{array}$ & 0.000 & 0.000 & 0.000 & . & 0.000 & 0.000 & 0.000 \\
\hline & Efficiency & 0.000 & 0.000 & 0.000 & 0.000 & . & 0.000 & 0.000 \\
\hline
\end{tabular}




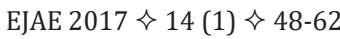

Mihajlović N. $\diamond$ The analysis of Serbian customers satisfaction with e-services quality dimensions of lodging e-intermediaries

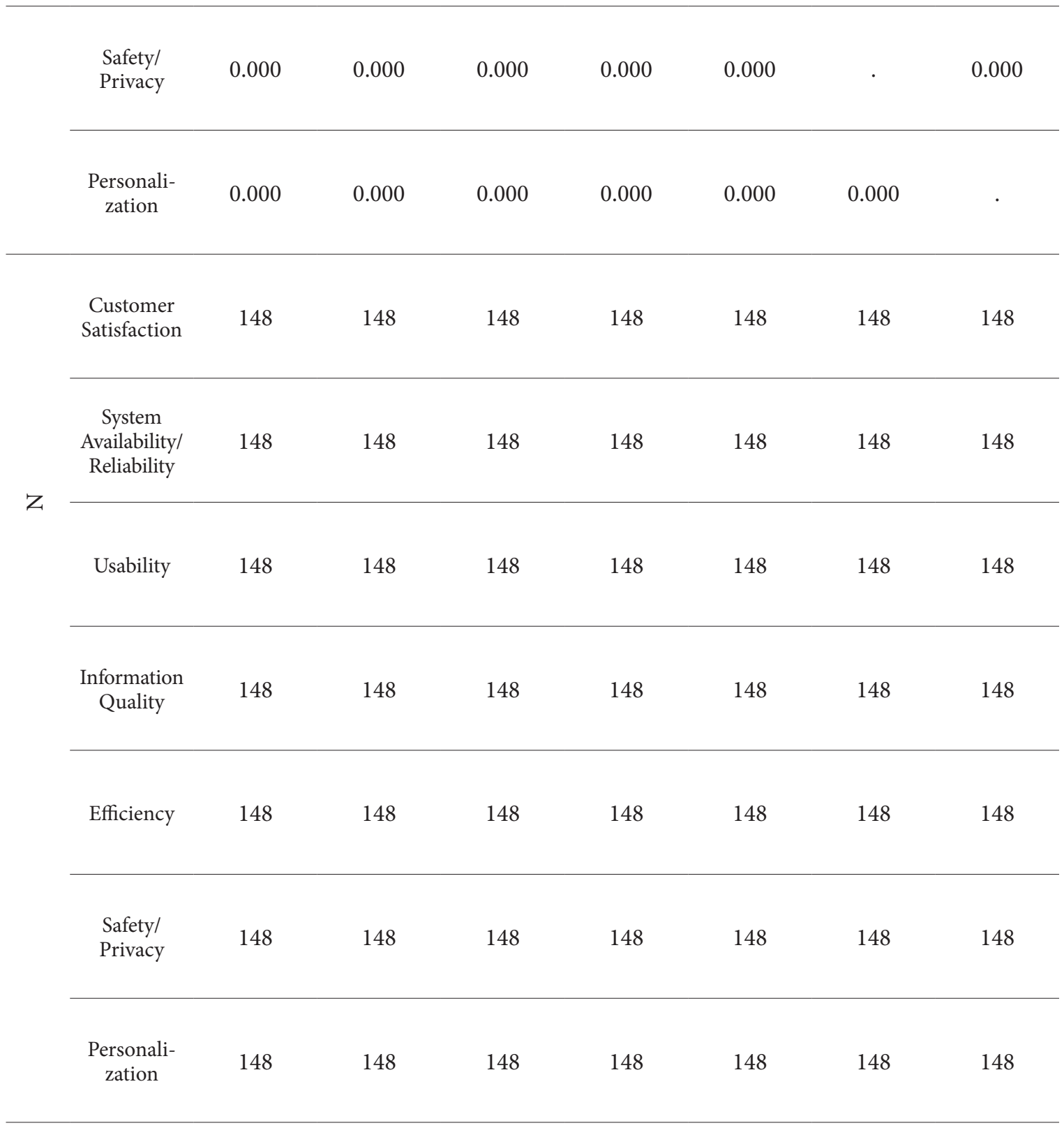

Table 2. - Pearson correlation matrix.

\begin{tabular}{|c|c|c|c|c|c|c|c|c|c|}
\hline \multirow{2}{*}{ Model } & \multirow{2}{*}{$\boldsymbol{R}$} & \multirow{2}{*}{ R Square } & \multirow{2}{*}{$\begin{array}{c}\text { Adjusted R } \\
\text { Square }\end{array}$} & \multirow{2}{*}{$\begin{array}{l}\text { Std. Error } \\
\text { of the } \\
\text { Estimate }\end{array}$} & \multicolumn{5}{|c|}{ Change Statistics } \\
\hline & & & & & $\begin{array}{l}\text { R Square } \\
\text { Change }\end{array}$ & F Change & $d f 1$ & $d f 2$ & $\begin{array}{c}\text { Sig. F } \\
\text { Change }\end{array}$ \\
\hline 1 & $0.808^{\mathrm{a}}$ & 0.653 & 0.639 & 0.517 & 0.653 & 44.308 & 6 & 141 & 0.000 \\
\hline \multicolumn{10}{|c|}{ a. Predictors: (Constant), System Availability/Reliability, Usability, Information Quality, Efficiency, Safety/Privacy, Personalization } \\
\hline pen & able: & ner Satis & on & & & & & & \\
\hline
\end{tabular}

Table 3. - Regression analysis - model summary. 


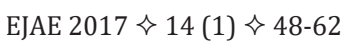

Mihajlović N. ^ The analysis of Serbian customers satisfaction with e-services quality dimensions of lodging e-intermediaries

\begin{tabular}{|c|c|c|c|c|c|c|c|c|c|c|}
\hline & \multirow{2}{*}{ Model } & \multicolumn{2}{|c|}{$\begin{array}{c}\text { Unstandardized } \\
\text { Coefficients }\end{array}$} & \multirow{2}{*}{$\begin{array}{c}\begin{array}{c}\text { Standardized } \\
\text { Coefficients }\end{array} \\
\text { Beta }\end{array}$} & \multirow{2}{*}{$t$} & \multirow{2}{*}{ Sig. } & \multicolumn{2}{|c|}{$\begin{array}{l}95.0 \% \text { Confidence } \\
\text { Interval for } B\end{array}$} & \multicolumn{2}{|c|}{$\begin{array}{c}\text { Collinearity } \\
\text { Statistics }\end{array}$} \\
\hline & & $B$ & $\begin{array}{l}\text { Std. } \\
\text { Error }\end{array}$ & & & & $\begin{array}{l}\text { Lower } \\
\text { Bound }\end{array}$ & $\begin{array}{l}\text { Upper } \\
\text { Bound }\end{array}$ & Tolerance & $V I F$ \\
\hline & (Constant) & 0.760 & 0.379 & & 2.005 & 0.047 & 0.011 & 1.509 & & \\
\hline & $\begin{array}{c}\text { System } \\
\text { Availability } \\
\text { /Reliability }\end{array}$ & 0.216 & 0.068 & 0.217 & 3.178 & 0.002 & 0.082 & 0.351 & 0.526 & 1.901 \\
\hline & Usability & -0.005 & 0.093 & -0.005 & -0.058 & 0.954 & -0.190 & 0.179 & 0.368 & 2.721 \\
\hline & $\begin{array}{l}\text { Information } \\
\text { Quality }\end{array}$ & 0.396 & 0.073 & 0.392 & 5.433 & 0.000 & 0.252 & 0.540 & 0.471 & 2.122 \\
\hline & Efficiency & 0.135 & 0.071 & 0.145 & 1.888 & 0.061 & -0.006 & 0.276 & 0.414 & 2.415 \\
\hline \multirow[t]{2}{*}{1} & $\begin{array}{l}\text { Safety/ } \\
\text { Privacy }\end{array}$ & -0.046 & 0.044 & -0.071 & -1.061 & 0.291 & -0.133 & 0.040 & 0.549 & 1.821 \\
\hline & $\begin{array}{l}\text { Persona- } \\
\text { lization }\end{array}$ & 0.231 & 0.049 & 0.316 & 4.677 & 0.000 & 0.133 & 0.329 & 0.539 & 1.855 \\
\hline
\end{tabular}

Table 4. - Coefficients.

The results (Table 3) show that e-SQ dimensions in this study provide an explanation for $63.9 \%$ of consumer satisfaction following that the coefficient of determination (R2) is 0.639 .
According to Cohen's rules for the effects sizes, the coefficient of determination over $13.8 \%$ is considered large (Cohen, 1998, as cited in Jitpaiboon $\&$ Rao, 2007).

\begin{tabular}{ccccccc}
\hline Model & $\begin{array}{c}\text { Sum of } \\
\text { Squares }\end{array}$ & df & $\begin{array}{c}\text { Mean } \\
\text { Square }\end{array}$ & F & Sig. \\
\hline 1 & Regression & 70.940 & 6 & 11.823 & 44.308 & $0.000^{\mathrm{b}}$ \\
\hline \multirow{2}{*}{ Residual } & 37.625 & 141 & 0.267 & & \\
\cline { 2 - 6 } & Total & 108.565 & 147 & & \\
\hline
\end{tabular}

a. Dependent Variable: Customer Satisfaction

b. Predictors: (Constant), System Availability/Reliability, Usability, Information Quality, Efficiency, Safety/Privacy, Personalization

Table 5. - ANOVA test.

ANOVA test (Table 5) showed that the used model was adequate, as the F-statistic $=44.308$ was significant at the $1 \%$ level $(\mathrm{p}<0.01)$ and that there is a statistically significant relationship between the e-SQ dimensions and customer satisfaction. On the other hand, it is necessary to check whether this applies to all e-SQ dimensions individually.
Based on the standardized regression coefficient $ß$ and $T$-static values at $p<0.01$ (Table $4)$, the individual model variables revealed that Information Quality (0.392), Personalization (0.316) and Reliability (0.217) have a significant and positive relationship on customer satisfaction. On the other hand, Efficiency although having 
a positive relationship $(\beta=0.145)$, is not statistically significant $(\mathrm{t}=1.888, \mathrm{p}>0.01)$, while Usability $(ß=-0.005, \mathrm{t}=-0.058, \mathrm{p}>0.01)$ and Safety $(ß=$ $-0.071, \mathrm{t}=-1.061, \mathrm{p}>0.01)$ show a negative effect on customer satisfaction, but their effect is not statistically significant.

\section{DISCUSSION}

This research has shown that there is a significant relationship between the e-SQ dimensions and Serbian customer satisfaction with the e-service of lodging e-intermediaries. The survey results clearly show that the research model used is reliable and valid.

Initial hypotheses were tested in order to resolve the research problem. E-SQ dimension means ranged (1 to 7) from 4.989, which was the mean for Safety, to 6.318 for Reliability. Correlation matrix showed that all e-SQ dimensions tested in this study have had a positive correlation with customer satisfaction.

Furthermore, the regression analysis showed that the Serbian user satisfaction is mainly affected by three e-SQ dimensions: Information Quality, Personalization and Reliability. Thus, the hypotheses related to these e-SQ dimensions have been confirmed. On the other hand, concerning the remaining three dimensions (Efficiency, Usability and Safety), although having some relationship with customer satisfaction, the effects were not statistically significant. Consequently, the hypotheses related to these e-SQ dimensions have been discarded. Table 6 shows the overview of the confirmed and discarded hypotheses.

\begin{tabular}{ll}
\hline \multicolumn{1}{c}{ Hypothesis } & Result \\
\hline Hypothesis 1: System Availability/Reliability has positive influence on e-SQ satisfaction & Confirmed \\
\hline Hypothesis 2: Structure/Usability has positive influence on e-SQ satisfaction & Discarded \\
\hline Hypothesis 3: Information Quality has positive influence on e-SQ satisfaction & Confirmed \\
\hline Hypothesis 4: Efficiency has positive influence on e-SQ satisfaction & Discarded \\
\hline Hypothesis 5: Safety/Privacy has positive influence on e-SQ satisfaction & Discarded \\
\hline Hypothesis 6: Personalization has positive influence on e-SQ satisfaction & Confirmed \\
\hline
\end{tabular}

Table 6. - Confirmed and discarded hypotheses.

The hypotheses testing proved that some of the e-SQ dimensions are positively affecting satisfaction of Serbian customers. On the other hand, if we compare the means of the respondents expressed satisfaction for e-SQ dimensions with the relationship of those dimensions with customer satisfaction, we come to the conclusion that Serbian customers are most satisfied with the reliability of lodging e-intermediaries, whose effect on satisfaction is the smallest. Customer satisfaction with the remaining two e-SQ dimensions that have proven to have effect on customer satisfaction is lower, and leaves room for improvement.
If we compare the results of this research with the results that Bauernfeind et al. acquired in Austria, it is evident that both studies have shown that the e-SQ dimensions have an effect on customer satisfaction. However, there are differences regarding which dimensions affect user satisfaction and which do not, meaning that there are differences in the perception of e-SQ of e-intermediaries in different regions and countries (Table 7).

Based on these differences, it is possible to conclude that the number of e-SQ dimensions is not exhaustive, and that further research is required to investigate a larger number of dimensions. 


\begin{tabular}{cc}
\hline Bauernfeind et al.(2006) & $\begin{array}{c}\text { Results of the } \\
\text { research on } \\
\text { Serbian customers }\end{array}$ \\
\hline Efficiency & Information Quality \\
\hline Personalization & Personalization \\
\hline Safety & Reliability \\
\hline
\end{tabular}

Table 7. - Differences in E-SQ dimensions affecting customer satisfaction across researches.

Given that this research was conducted on a convenient sample and that the sample is relatively small, this study cannot be considered as representative, but as a starting point for further research.

\section{CONCLUSIONS}

Customer satisfaction in this study was conceptually set very narrow within the framework of the six e-SQ dimensions. Following that the e-SQ dimensions show variation in representing the customer satisfaction with a total of $63.9 \%$, there is a significant space of $36.1 \%$ of variation explained by factors which are not examined herein. The study refers to the perception of satisfaction with e-service offered by lodging eintermediaries exclusively, and therefore has limited use when it comes to other types of websites and e-intermediaries in different industries. The information quality has shown the largest effect on customer satisfaction in this study. There is a possibility that in different circumstances and/or environment, some other dimensions may show a much greater importance. This research has shown that the e-SQ dimensions have an essential role in achieving the customer satisfaction. The results also show that there is a possibility for further improvement of lodging e-intermediary services as the customers are not fully satisfied with the most significant e-SQ dimensions. Also, the results and the differences in the results of this and other studies show that it is necessary to further improve the personalization of websites and adapt them to customers from different regions and countries.

Partial differences in the results of this study compared to other studies indicate that, due to the changing preferences of customers and their perception of the quality, there is a necessity to conduct analyses of the perception of the e-SQ on a regular basis, in order to be up-to-date with the ever changing needs and expectations of customers. Also, the differences in the e-SQ dimensions that have effects on customer satisfaction indicate that it is necessary to set up a broader research framework involving a larger number of e-SQ dimensions for further research.

\section{REFERENCES}

Alonso-Almeida, M., Bernardo, M., Llach, J., \& Marimon, F. (2014). Building loyalty through functional and hedonic quality. Industrial Management \& Data System, 114, 387-404.

Avdimiotis S., Bonarou, C., Dermetzopoulos, A., Ioannis Karamanidis, I., Thomas Mavrodontis, T., Kelessidia, V., \& Kalonaki, E. (2009). Global SWOT Analysis, a report produced for TOUREG Project, Deliverable D.2.1. Greece: Alexander Technological Educational Institute of Thessaloniki and the Technical University of Crete

Barnes, S.J., \& Vidgen, R.T. (2002). An Integrative Approach to the Assessment of E-Commerce Quality. Journal of Electronic Commerce Research, 3(3), 114-127.

Bauernfeind, U., Mayr, T., \& Zins, A.H. (2006). A conceptual model for quality dimensions for b2c recommender systems. In Fourteenth European Conference on Information Systems - ECIS, 2006 (1007-1018). Gothenburg, Sweden: Association for Information Systems 
Bernardo, M., Marimon, F., \& Alonso-Almeida, M.M. (2012). Functional quality and hedonic quality: a study of the dimensions of e-service quality in online travel agencies. Information \& Management, 49(7-8), 342-347.

Bogdanovych, A., Esteva, M., Gu, N., Simoff, S., Maher M.L. \& Smith. G. (2007). The Role of Online Travel Agents in the Experience Economy. In International Conference on Information Technology in Tourism ENTER 2007. Wien, Austria: Springer-Verlag Wien

Buhalis, D. \& Licata, M.C. (2001). The Future eTourism intermediaries. Tourism Management, 23(3), 207 220. DOI: 10.1016/S0261-5177(01)00085-1

Cristobal, E., Flavian, C., \& Guinaliu, M. (2007). Perceived E-Service Quality: Measurement Validation and Effects on Consumer Satisfaction and Website Loyalty. Managing Service Quality: An International Journal, 17(3), 317-340. DOI: 10.1108/09604520710744326

Cyr, D. (2008). Modelin Website Design across Cultures: Relationship to Trust, Satisfaction and E-loyalty. Journal of Management Information Systems, 24(4), 47-72. DOI: 10.2753/MIS0742-1222240402

Davidson, A.P., \& Burgess, S. (2006). E-commerce in tourism: use of websites by small regional and urban enterprises. Gold Coast, Queensland, Australia: CRC for Sustainable Tourism.

Jitpaiboon, T., \& Rao, S.S. (2007). A meta-analysis of quality measures in manufacturing system. International Journal of Quality \& Reliability Management, 24(1), 78-102. DOI: 10.1108/02656710710720349

Kovačević, M., Pavlović, K., \& Šutić, V. (2015). Upotreba informaciono-komunikacionih tehnologija u republici Srbiji, 2015. Beograd: Republički zavod za statistiku. In Serbian.

Lee, G., \& Lin, H. (2005). Customer perceptions of eservice quality in online shopping. International Journal of Retail \& Distribution Management, 33(2), 161-176. DOI: 10.1108/09590550510581485

Loiacono, E., Chen, D., \& Goodhue, D. (2002). WebQual $^{\text {Ts }}$ Revisited: Predicting the Intent to Reuse a Web Site. In 8th Americas Conference on Information Systems - AMCIS 2002, Paper 46, Dallas, USA: Association for Information Systems

Marimon, F., Vidgen, R., Barnes, S. \& Cristobal, E. (2010). Purchasing behaviour in an online supermarket: the applicability of E-S-QUAL. International Journal of Market Research, 52(1), 111-129. DOI: $10.2501 /$ S1470785310201089
Parasuraman, A., Zeithaml, V.A., \& Malhotra, A. (2005). E-S-QUAL: A Multiple-Item Scale for Assessing Electronic Service Quality. Journal of Service Research, 7(3), 213-233. DOI: $10.1177 / 1094670504271156$

Popesku, J. (2011). Menadžment turističke destinacije. Beograd: Univerzitet Singidunum. In Serbian

Raman, M., Stehenaus, R., Alam, N., \& Kuppusamy, M. (2008). Information Technology in Malaysia: E-Service Quality and Uptake of Internet Banking. Journal of Internet Banking and Commerce, 13(2), 1-18.

Sekaran, U., \& Bougie, R. (2010). Research methods for business: A skill building approach (5th ed.). Chichester, UK: John Willey \& Sons Ltd.

Serkan, A., Eda, A., \& Safak, A. (2010). Re-assessment of E-S-Qual and E-RecS-Qual in a pure service setting. Journal of Business Research, 63, 232-240. DOI: 10.1016/j.jbusres.2009.02.018

Swaid, S.I., \& Wigand, R.T. (2009). Measuring the quality of e-service: Scale development and initial validation. Journal of Electronic Commerce Research, 10(1), 13-28.

Udo, G.J., Bagchi, K.K. \& Kirs, P.J. (2010). An assessment of customers' e-service quality perception, satisfaction and intention. International Journal of Information Management, 30, 481-492. DOI: 10.1016/j.ijinfomgt.2010.03.005

Vitić-Ćetković, A. (2009). Inovacije u tehnologiji i ekonomija znanja - refleksija na globalne marketing tokove hotelijerstva. Turističko poslovanje, 4, 189-196. In Serbian.

Vukmirović, D., Pavlović, K., \& Šutić, V. (2012).Upotreba informaciono-komunikacionih tehnologija u republici Srbiji, 2012.Belgrade, Serbia: Republički zavod za statistiku. In Serbian.

Wolfinbarger, M., \& Gilly, M.C. (2003). eTailQ: dimensionalizing, measuring and predicting etail quality. Journal of Retailing, 79(3), 183-198. DOI: 10.1016/ S0022-4359(03)00034-4

World Travel Market (2015). WTM Global Trends Report 2015. London, UK: World Travel Market.

Yoo, B., \& Donthu, N. (2001). Developing a Scale to Measure the Perceived Quality of an Internet Shopping Site (SITEQUAL). Quarterly Journal of Electronic Commerce, 2(1), 31-47. DOI: 10.1007/9783-319-11885-7_129

Zeithaml, V.A., Bitner, M. J. \& Gremler, D. D. (2009). Services Marketing: Integrating Customer Focus across the Firm (5th ed.). New York, USA: McGraw Hill. 
Zeithaml, V.A., Parasuraman, A. \& Malhorta, A. (2002). Service quality delivery through web sites- a critical review of extant knowledge. Journal of the Academy of Marketing Science, 30(4), 362-375. DOI: $10.1177 / 009207002236911$

Santouridis, I., \& Krikoni, E. (2016). Extending E-SQUAL with hedonic dimensions to measure the quality of internet travel services and its effects on perceived value, loyalty and switching barriers. International Journal of Technology Marketing, 11(3), 301-318. DOI: 10.1504/IJTMKT.2016.077395

Smith, A.A., \& Synowka, D.P. (2014). E-commerce quality and adoptive elements of e-ticketing for entertainment and sporting events. International Journal of Business Information Systems, 15(4), 450-48. DOI: 10.1504/IJBIS.2014.060397
Satapathy, S., Patel, S.K., Biswas, A. \& Mishra, P.D. (2013). A methodology to measure the service quality of online shopping of electronic goods in India. International Journal of Indian Culture and Business Management, 6(2), 227-247. DOI: 10.1504/ IJICBM.2013.052002

$\mathrm{Su}, \mathrm{Q}$. (2014). Research of instrument to measure customer perceived service quality of mobile data services. International Journal of Networking and Virtual Organisations, 14(1/2), 176-196. DOI: 10.1504/ IJNVO.2014.065101 